SAKAI SAMBAYAN — Jurnal Pengabdian kepada Masyarakat

\title{
PEMANFAATAN LAMPU TENAGA SURYA SEBAGAI LAMPU PENERANGAN JALAN DI PEKON KILUAN NEGERI KABUPATEN TANGGAMUS
}

\author{
Sumadi ${ }^{*}$, Sri Ratna Sulistiyanti, FX. Arinto Setyawan \\ Jurusan Teknik Elektro Universitas Lampung, Bandar Lampung \\ Jl. Prof. Sumantri Brojonegoro No.1 Bandar Lampung 35145 \\ Penulis Korespodensi : sumadi.1973@eng.unila.ac.id
}

\begin{abstract}
Abstrak
Pekon Kiluan Negeri, Kecamatan Kelumbayan, Kabupaten Tanggamus merupakan destinasi wisata unggulan provinsi Lampung. Selain keindahan panorama daerah, daerah ini juga menawarkan fasilitas yang berbeda dengan daerah obyek wisata lainnya, yaitu pengamatan lumba-lumba di laut lepas. kekurangan yang ada pada daerah ini adalah minimnya penerangan jalan pada malam hari. Hal ini memberi kesan kurang aman pada daerah wisata ini. Kekurangan ini dipicu karena kurangnya pasokan energi listrik ke daerah ini sehingga masyarakat lebih mementingkan memenuhi kebutuhan listrik rumah tanga mereka terlebih dahulu. Selain itu tegangan listrik dari PLN yang tidak stabil seringkali merusakkan peralatan listrik yang ada. Melihat kenyataan tersebut, timbul permasalahan bagaimana cara mengenalkan teknologi pembangkit listrik tenaga surya (matahari) ini. Cara yang paling mudah adalah dengan memanfaatkan energi surya ini sebagai energi alternatif untuk fasilitas penerangan jalan umum. Diharapkan semua warga merasa memiliki terhadap peralatan yang ada ini dan turut menjaga keawetannya. Dari kegiatan ini, telah terpasang satu unit lampu penerangan jalan berbasis PLTS, dan pemahaman serta keterampilan masyarakat Pekon Kiluan Negeri dalam mempersiapkan, pengoperasian, dan perawatan lampu jalan.
\end{abstract}

Kata kunci: lampu penerangan jalan, tenaga surya, kenyamanan

\section{Pendahuluan}

Pekon Kiluan Negeri, Kecamatan Kelumbayan, Kabupaten Tanggamus merupakan destinasi wisata unggulan provinsi Lampung. Selain keindahan panorama daerah, daerah ini juga menawarkan fasilitas yang berbeda dengan daerah obyek wisata lainnya, yaitu pengamatan lumba-lumba di laut lepas. Untuk kegiatan ini, masyarakat setempat memberikan jasa penyewaan perahu yang cukup murah. Keunikan ini membawa daerah ini berhasil menjadi juara pertama lomba pekon wisata tahun 2015 di Provinsi Lampung.

Salah satu kekurangan yang ada pada daerah ini adalah minimnya penerangan jalan pada malam hari. Hal ini memberi kesan kurang aman pada daerah wisata ini. Kekurangan ini dipicu karena kurangnya pasokan energi listrik ke daerah ini sehingga masyarakat lebih mementingkan memenuhi kebutuhan listrik rumah tanga mereka terlebih dahulu. Selain itu tegangan listrik dari PLN yang tidak stabil seringkali merusakkan peralatan listrik yang ada.
Penggunaan energi alternatif bertenaga surya ini sangat cocok diterapkan sebagai sumber energi untuk penerangan jalan. Hal ini karena potensi sumber cahaya matahari yang besar di daerah ini untuk dapat dikonversi menjadi energi listrik. Selain itu, penerangan jalan berbasis energi surya ini dapat dirancang independen satu sama lain sehingga tidak membutuhkan kabel instalasi yang mengganggu keindahan.

Sebelumnya telah ada bantuan dari pemerintah berkaitan dengan pembangkit listrik bertenaga surya untuk daerah ini tetapi telah banyak yang rusak. Hal ini disebabkan minimnya pengetahuan warga akan teknologi bertenaga surya ini. Bantuan tersebut diberikan untuk perumahan pribadi bukan untuk fasilitas umum sehingga warga merasa kurang memiliki terhadap bantuan ini. Selain itu, kesan mahal terhadap peralatan yang digunakan menambah ketidakpedulian mereka terhadap kerusakan peralatan pembangkit bertenaga surya ini.

Melihat kenyataan tersebut, timbul permasalahan bagaimana cara mengenalkan 
teknologi pembangkit listrik tenaga surya (matahari) ini. Pengenalan ini sekaligus untuk memberikan gambaran bahwa penyediaan energi listrik membutuhkan biaya yang besar sehingga perlu penghematan dalam menggunakannya. Cara yang paling mudah adalah dengan memanfaatkan energi surya ini sebagai energi alternatif untuk fasilitas penerangan jalan umum. Diharapkan semua warga merasa memiliki terhadap peralatan yang ada ini dan turut menjaga keawetannya. Diharapkan pula warga akan tergugah untuk memanfaatkan teknologi ini setelah merasakan manfaat yang didapatkan sehingga timbul keinginan untuk memasang lampu penerangan berbasis energi surya ini di tempat-tempat lain yang memerlukan.

Potensi pembangkit listrik tenaga surya di Indonesia cukup menjanjikan karena Indonesia tergolong negara yang kaya akan energi surya ini. Di Indonesia, pada kondisi puncak atau posisi matahari tegak lurus, sinar matahari yang jatuh di permukaan panel surya untuk seluas satu meter persegi akan mampu mencapai 900 hingga 1000 Watt. Sedangkan total intensitas penyinaran perharinya di Indonesia mampu mencapai 4500 watt hour per meter persegi.

Mencermati kondisi di atas maka Universitas Lampung sebagai institusi perguruan tinggi di Provinsi Lampung yang mempunyai komitmen untuk mengembangkan penggunaan teknologi, berupaya untuk meningkatkan wawasan tentang adanya energi alternatif yang bersumber pada sinar matahari yang dapat dikonversi menjadi energi listrik. Pemanfaatan tenaga surya sebagai energi alternatif untuk penerangan jalan ini memiliki harapan agar semakin banyak yang menggunakannya.

Adapun perumusan masalahannya adalah sebagai berikut:

1. Banyak yang belum mengetahui adanya energi alternatif yang dapat dimanfaatkan menjadi sumber energi listrik agar dapat dimanfaatkan untuk keperluan sehari-hari.

2. Banyak warga pekon yang tidak mengetahui bahwa sinar matahari dapat dikonversi menjadi energi.

3. Oleh karena itu perlu dilakukan pengenalan sejak dini terhadap adanya energi alternatif ini kepada warga pekon Kiluan Negeri Kabupaten Tanggamus agar tertarik mengembangkan teknologi ini dimasa depannya. adalah:

Adapun tujuan dan manfaat kegiatan ini

1. Meningkatkan peran Universitas Lampung dalam pembinaan masyarakat di Pekon Kiluan Negeri, Kecamatan Kelumbayan, kabupaten Tanggamus, provinsi Lampung.

2. Melakukan transfer teknologi khususnya teknologi berbasiskan energy surya kepada masyarakat di Pekon Kiluan Negeri, Lampung.

3. Meningkatkan kreatifitas masyarakat di Pekon Kiluan Negeri untuk memanfaatkan pembangkit listrik bertenaga surya untuk keperluan lainnya.

\section{Tinjauan Pustaka}

Besarnya peningkatan kebutuhan akan energy listrik saat ini tidak mampu diimbangi dengan penambahan penyedian energy listrik oleh PLN. Hal ini disebabkan karena sumber daya yang dapat diubah menjadi tenaga listrik dengan harga murah sangatlah terbatas. Peningkatan kebutuhan akan energy listrik ini dipicu semakin banyaknya peralatan yang menggunakan energy listrik sebagai sumber energy utamanya.

Sebenarnya terdapat sumber daya lain yang dapat digunakan sebagai sumber energy listrik yaitu cahaya matahari. Ini merupakan sumber energy yang terdapat sangat melimpah terutama di Indonesia yang merupakan negara tropis. Cahaya matahari saat ini merupakan sumber energy listrik alternative yang mulai banyak digunakan untuk skala kecil (rumah tangga). Efisiensi dan modal instalasi awal yang besar merupakan alasan sumber ini kurang berkembang secara cepat. Selain itu, pemeliharaan yang terkesan sulit juga merupakan alasan lain.

Pembangkit listrik tenaga surya memiliki komponen utama berupa Photovoltaik. Komponen ini berfungsi mengubah panas matahari menjadi listrik. Proses penyimpanan energy pembangkit listrik tenaga surya skala rumah tangga ini diperlihatkan pada Gambar 1. Proses pertama yang dilakukan adalah energy panas diubah menjadi listrik oleh panel surya kemudian melalui pengendali charger disimpan dalam baterai. Energi yang disimpan adalah dalam bentuk tegangan arus searah. Jika dipergunakan untuk peralatan DC maka energy yang tersimpan dalam baterai dapat dipergunakan secara langsung tetapi jika dipergunakan untuk peralatan $\mathrm{AC}$ maka harus 
diubah dahulu manjadi tegangan arus bolak-balik menggunakan inverter.

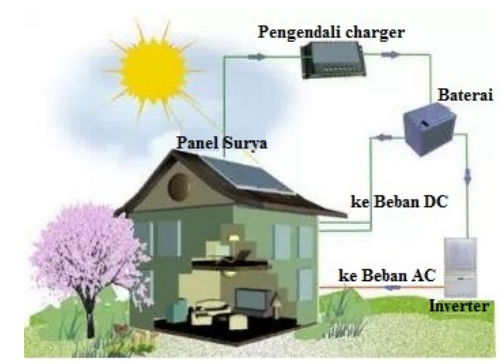

Gambar 1. Proses pengubahan energi dari energi surya menjadi listrik.

Bahan panel sel surya yang paling umum adalah crystalline silicon. Bahan crystalline dapat terdiri dari single crystal, mono or singlecrystalline, dan poly atau multi-crystalline. Selain itu panel sel surya ada yang terbuat dari lapisan tipis amorphous silicon. Sel Crystalline silicon mempunyai 2 tipe yang hampir serupa, meskipun sel single crystalline lebih efisien dibandingkan dengan poly-crystalline karena poly-crystalline merupakan ikatan antara sel-sel. Keunggulan dari amorphous silicon adalah harga yang terjangkau tetapi tidak seefisien sel surya crystalline silicon.

PJU (Penerangan Jalan Umum) adalah lampu yang digunakan untuk penerangan jalan dimalam hari sehingga mempermudah pejalan kaki, pesepeda dan pengendara kendaraan agar dapat melihat dengan lebih jelas jalan/medan yang akan dilalui pada malam hari. Tujuan adalah untuk meningkatkan keselamatan lalu lintas dan keamanan para pengguna jalan dari aksi criminal dan juga memberikan keindahan lingkungan jalan.

Kriteria perencanaan penerangan jalan terkait dengan hal-hal berikut ini :

- Volume lalu-lintas

- Situasi (lay-out) jalan

- Geometri jalan

- Pemilihan jenis dan kualitas sumber cahaya/lampu

- Biaya operasi dan biaya pemeliharaan

- Rencana jangka panjang pengembangan jalan dan pengembangan daerah sekitarnya;

- Data kecelakaan dan kerawanan di lokasi.

Karena pemasangan dilakukan dipertigaan maka dirancang sinar lampu dapat menerangi 3 arah lokasi jalan. Rancangan penempatan lampu diperlihatkan pada Gambar 2. Volume lalu-lintas tempat pemasangan JPU merupakan pertigaan menuju daerah wisata teluk kiluan. Volume lalu lintas masih cukup sepi sehingga hanya memerlukan penerangan yang sederhana, oleh karena itu dirancang PJU yang menggunakan lampu LED yang cukup awet dan terang. Pemilihan Lampu LED DC untuk PJU dikarenakan sumber energi listrik yang digunakan adalah energi dari panas matahari yang disimpan dalam aki yang merupakan tegangan arus searah (DC) sehingga tidak memerlukan inverter yang cukup mahal.

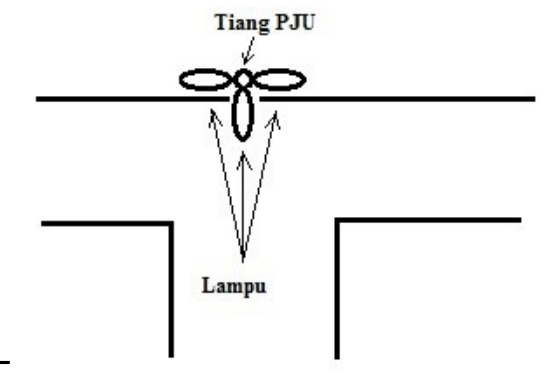

Gambar 2. Rancangan peletakan lampu PJU untuk persimpangan.

Dalam pembangkit listrik tenaga surya, panel surya merupakan peralatan terpenting. Walaupun panel surya umumnya bergaransi cukup lama (5 hingga 25 tahun) tetapi perawatan tetaplah penting agar tidak menganggu kinerja pembangkit. Terdapat beberapa pertimbangan dalam memilih panel surya, yaitu:

1. Efisiensi panel surya, semakin besar efisiensinya maka semakin besar pula energi yang dapat dikonversi oleh panel surya untuk ukuran yang sama.

2. Daya tahan, penggunaan panel surya yang memiliki daya tahan bagus memperkecil kemungkinan rusak sehingga tidak merepotkan dalam hal perawatan.

3. Dimensi panel surya, perlu pertimbangan berdasarkan kondisi daerah.

Layanan purna jual, kemudahan mendapatkan layanan purna jual merupakan pertimbangan terakhir.

\section{Metode Pelaksanaan}

Dari kondisi yang dikemukakan dalam analisis situasi maka pemecahan masalah-masalah yang telah dirumuskan di atas dilakukan dalam bentuk instalasi PLTS pada jalan utama dan cara pemeliharaanya di pekon Kiluan Negeri kabupaten Tanggamus dan melibatkan warga masyarakat selama proses instalasi. Warga masyarakat juga diberikan pengetahuan tentang PLTS dan prinsip 
kerjanya serta cara-cara pemeliharaan peralatan PLTS agar awet dan tahan lama.

Khalayak sasaran dari kegiatan ini adalah warga pekon di Pekon Negeri Kiluan Kabupaten Tanggamus dengan jumlah peserta 10 orang.

Metode yang digunakan dalam kegiatan ini adalah instalasi PLTS oleh tim pengabdian dan penyampaian penjelasan tentang PLTS untuk penerangan jalan umum kepada warga masyarakat. Adapun susunan kegiatannya adalah sebagai berikut:

1. Tim pengabdian memberikan penjelasan kepada warga tentang PLTS skala kecil dan prinsip kerjanya serta cara pemeliharaanya.

2. Instalasi PLTS untuk penerangan jalan umum di jalan utama pekon dengan melibatkan warga setempat.

Uji coba keberhasilan instalasi.

\section{Hasil dan Pembahasan}

Kegiatan pengabdian masyarakat ini telah selesai dan berhasil dilaksanakan. PLTS untuk penerangan jalan umum telah dipasang di jalan utama pekon Kiluan Negeri kabupaten Tanggamus. Instalasi dilakukan dengan metode bottom-up yang artinya setelah sistem terpasang kemudian dilakukan evaluasi per tahapannya. Evaluasi pertama yaitu mengecek besaran arus dan tegangan pada aki. Kemudian mengevaluasi ke perangkat elektronik yang terhubung dengan PLTS.

Keberhasilan pemasangan PJU diketahui dengan melakukan ujicoba terhadap perangkat lampu jalan. Pertama pada lampu yang terdiri dari lampu LED DC, dan lampu biasa. Lampu berhasil menyala yang artinya panel surya, aki dan kabel berfungsi dengan baik. Hasil menunjukkan bahwa peralatan tersebut dapat berfungsi. PJU ini difungsikan secara otomatis dimana pada saat siang hari lampu PJU akan mati dan pada saat malam hari lampu akan menyala secara otomatis. Gambar 3 memperlihatkan lampu pada saat siang hari dan malam hari.

PLTS yang tidak memerlukan bahan bakar tentu saja menjadi pilihan yang tepat terutama dari segi penghematan biaya. Besaran biaya untuk investasi awal pun hampir sama dengan investasi awal genset. Hanya saja genset memerlukan bahan bakar yang kontinu sedangkan PLTS tidak memerlukan bahan bakar karena sumber energinya adalah sinar matahari.

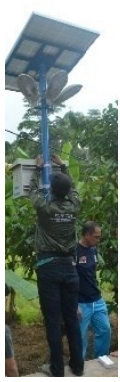

(a)

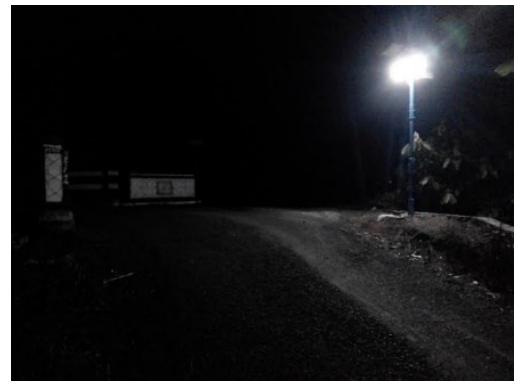

(b)
Gambar 3. Kondisi lampu PJU:

(a) Pada siang hari

(b) Pada malam hari

\section{Kesimpulan}

Dari hasil kegiatan pengabdian kepada masyarakat yang telah dilaksakan ini dapat disimpulkan beberapa hal, yaitu pemberian materi mengenai cara pemeliharaan peralatan PLTS telah disampaikan disertai praktik secara langsung dan PLTS untuk penerangan jalan umum telah berhasil dipasang di jalan utama pekon Kiluan Negeri Kabupaten Tanggamus, sehingga dapat memberikan penerangan di malam hari.

\section{Ucapan Terima Kasih}

Ucapan terima kasih terutama ditujukan kepada LPPM Universitas Lampung yang telah memberikan dana untuk kegiatan pengabdian kepada masyarakat, tahun anggaran 2017.

\section{Daftar Pustaka}

D. B. Limbong, S. T. Kasim, Perbandingan Teknis Dan Ekonomis Penggunaan Penerangan Jalan Umum Solar Cell Dengan Penerangan Jalan Umum Konvensional, Singuda Ensikom, Vol. 8, No. 3, pp. 146-151, 2014.

Rusman, Pengaruh Variasi Beban Terhadap Efisiensi Solar Cell Dengan Kapasitas 50 Wp, Turbo Jurnal Teknik Mesin Universitas Muhamadiyah Metro, Vol. 4, No. 2, pp. 84-90, 2015

S. Kurniati dan Sudirman, Analisis Efisiensi Keluaran Daya Solar Sel Berdasarkan Sudut Kemiringan, Jurnal Media Elektro, Vol. 1 No. 3, pp. 85-88, 2013.

Suherman dan Bakhtiar, Efisiensi Energi Listrik Lampu Penerangan Menggunakan Sensor Inframerah, The 4th National Conference on Industrial Electrical and Electronics (NCIEE), pp. 1-3, 2016.

http://lampung.tribunnews.com/2015/12/01/pekonkiluan-negeri-juara-i-lomba-pekon-wisata-dilampung diakses tanggal 28 Agustus 2017. 